\title{
LEG LENGTH DISCREPANCY IN ADOLESCENT IDIOPATHIC SCOLIOSIS
}

\author{
DISMETRIA DOS MEMBROS INFERIORES NA ESCOLIOSE IDIOPÁTICA DO ADOLESCENTE \\ DISCREPANCIA DE LA LONGITUD DE LAS PIERNAS EN LA ESCOLIOSIS IDIOPÁTICA \\ DEL ADOLESCENTE
}

\author{
Eduardo Moreira Pinto, ${ }^{1}$ Jorge Alves, ${ }^{2}$ Alfredo Mendes de Castro, ${ }^{3}$ Marcos Silva, ${ }^{2}$ José Miradouro, $^{2}$ Artur Teixeira, ${ }^{1}$ António Miranda ${ }^{1}$ \\ 1. Entre Douro e Vouga Hospital Center, Orthopaedic Surgery and Traumatology Division, Santa Maria da Feira, Portugal. \\ 2. Tâmega e Sousa Hospital Center, Orthopaedic Surgery and Traumatology Division, Penafiel, Portugal. \\ 3. São João University and Hospital Center, Porto, Portugal.
}

\begin{abstract}
Objective: The objective of this study is to evaluate leg length discrepancy in adolescent idiopathic scoliosis. Methods: A retrospective study of 80 subjects with adolescent idiopathic scoliosis (AIS) was conducted. The inclusion criteria were patients aged 10 to 18 years old with posteroanterior (PA) and lateral full-length radiographs. The exclusion criteria were patients subjected to surgery or orthotic treatment, those with other spinal disease, and those with poor quality x-rays. The parameters evaluated were: age, sex, Risser stage (RS), triradiate cartilage (TC), scoliotic curvatures, differentiated according to Lenke classification, sagittal (SB) and coronal balance (CB), and leg length discrepancy, which was assessed through the difference between the femoral heads (LLD) and through the assessment of pelvic obliquity (PO). Results: The majority of patients with AIS demonstrated a mild LLD (<1 cm). The mean LLD was significantly different $(p<0.01)$ between the scoliotic population with a main thoracolumbar curvature and those with a main lumbar curvature. When there was an LLD, it was the left limb that was shortened in most cases. The side of the longer lower limb had a direct influence on the CB $(p=0.052)$. Conclusions: This study demonstrates that in an AIS population with small LLD values, the extent of the shortening has a stronger impact on coronal balance and location than on the dimension of the main scoliotic curvature. These results demonstrate the importance of a more in-depth study on the effects of LLD $<1 \mathrm{~cm}$ in the development of AIS and coronal imbalance. Level of evidence IV; Case Series.
\end{abstract}

Keywords: Scoliosis; Adolescent; Spine.

\section{RESUMO}

Objetivo: O objetivo deste estudo é avaliar a discrepância no comprimento dos membros inferiores numa população com escoliose idiopática do adolescente. Métodos: Foi realizado um estudo retrospetivo de 80 indivíduos com escoliose idiopática do adolescente (AIS). Os critérios de inclusão foram pacientes de 10 a 18 anos com radiografias coronais e sagitais extralongas, excluindo-se aqueles submetidos à cirurgia ou tratamento com coletes Milwaukee ou Boston, com outras doenças da coluna vertebral ou com exames que não cumpriam a qualidade radiográfica protocolada pelo Centro Hospitalar. Os parâmetros avaliados foram: idade, sexo, estadio de Risser (RS), cartilagem trirradiada (TC), curvaturas escolióticas diferenciadas segundo a classificação de Lenke, balanço sagital (SB), coronal (CB) e discrepância no comprimento dos membros inferiores, avaliado pelo desnivel entre as cabeças femorais (LLD) e através da avaliação da obliquidade pélvica (PO). Resultados: A maioria dos pacientes com AlS demonstrou LLD ligeira (<1 cm). A média de discrepância no comprimento dos membros inferiores foi significativamente diferente $(p<0,01)$ entre a população escoliótica com uma curvatura toracolombar principal em relação àquela com uma curvatura lombar principal. Quando existe LLD, o membro esquerdo encontra-se encurtado na maioria dos casos e a discrepância dos membros inferiores influencia diretamente no balanço coronal ( $p=0,052)$. Conclusão: A partir deste estudo, verificamos que, na população com AlS com pequenos valores de LLD, a magnitude do encurtamento tem um impacto de maior relevo no equilíbrio coronal e na localização do que na dimensão da curvatura escoliótica principal. Estes resultados levantam a importância de um estudo mais aprofundado sobre a importância da LLD $<1 \mathrm{~cm}$ no desenvolvimento de AIS e no desequilíbrio coronal. Nível de evidência IV; Série de Casos.

Descritores: Escoliose; Adolescente; Coluna Vertebral.

\section{RESUMEN}

Objetivos: El objetivo de este estudio es evaluar la diferencia de la longitud de los miembros inferiores en la escoliosis idiopática del adolescente. Métodos: Se realizó un estudio retrospectivo de 80 pacientes con escoliosis idiopática de adolescente (EIA). Los criterios de inclusión fueron los pacientes de 10 a 18 años con radiografías posteroanteriores (PA) y laterales de longitud completa. Los criterios de exclusión fueron los pacientes sometidos a cirugía o tratamiento ortopédico, aquellos con otra enfermedad de la columna y aquellos con radiografías de mala calidad. Los parámetros evaluados fueron: edad, sexo, estadio Risser (RS), cartílago trirradiado (CT), curvaturas escolióticas, diferenciadas según la clasificación de Lenke, balance sagital (BS) y coronal (BC) y discrepancia en la longitud de la pierna $(D L P)$, que se evaluó a través de la diferencia entre las cabezas femorales y mediante la evaluación de la oblicuidad pélvica (OP). Resultados: La mayoría de los pacientes con EIA demostró DLP leve $(<1 \mathrm{~cm})$. La media de la DLP fue significativamente distinta $(p<0,01)$ entre la población escoliótica con una curvatura toracolumbar principal y los pacientes con curvatura lumbar principal. Cuando había DLP, la extremidad izquierda se acortaba en la mayoría de los casos. El lado de la extremidad más larga tuvo influencia directa en el BC 
( $p=0$,052). Conclusiones: Este estudio demuestra que en una población con ElA y bajos valores de DLP, la extensión del acortamiento tiene impacto mayor en el balance y la ubicación coronal que en la dimensión de la curvatura escoliótica principal. Estos resultados muestran la importancia de un estudio más profundo sobre los efectos de DLP $<1 \mathrm{~cm}$ en el desarrollo de EIA y el desequilibrio coronal. Nivel de evidencia - IV; Serie de Casos.

Descriptores: Escoliosis; Adolescente; Columna Vertebral.

\section{INTRODUCTION}

Approximately 3 to $15 \%$ of population has a limb length discrepancy (LLD) of around $1 \mathrm{~cm}$; in $95 \%$ of cases, the causes are unknown. ${ }^{1,2}$

LLD causes pelvic obliquity in the frontal plane ${ }^{2}$ and leads to posture deformation, gait asymmetry, low back pain, discopathy, gonarthrosis, coxarthrosis and hip flexion contracture in the longer extremity or ankle joint contracture in the equinal position in the shorter extremity. ${ }^{3-6}$ In these cases, the LLD is due to asymmetrical load on the lower extremities..$^{7-10}$ Measurement of LLD, and the patient's age, are the most important factors in the management of this disease. ${ }^{11}$ Adolescent idiopathic scoliosis (AIS) affects approximately 1 to $3 \%$ of adolescents, and is more common in females. ${ }^{12}$ The progression of the curve and the effectiveness of the treatment are determined by the patient's age and sex, the magnitude and pattern of the curvature, and skeletal maturity. ${ }^{13-15}$

Full-length radiographs are essential in the analysis of biomechanical alterations that culminate in structural deficits of the axial skeleton and lower limbs. ${ }^{16}$ An appropriate and reproducible posture that presents a lower translation of the sagittal balance and lower compensatory rotation of the pelvis, with consequent reproducible results of the spinopelvic parameters and a smaller influence on the size of the natural curvatures of the axial skeleton, is essential for ensuring the quality of the data collected. ${ }^{17-21}$

Our goal is to determine the influence of LLD on spinopelvic parameters, magnitude of spine curvatures and changes in the coronal and sagittal balance, in a population with AIS.

\section{METHODS}

\section{Population}

The sample was composed of 80 patients with AIS. The inclusion criteria were patients with PA and lateral full-length radiographs. The exclusion criteria were patients who had undergone surgery, those who had initiated orthotic treatment, and those with poor quality radiographs (without inclusion from $\mathrm{C} 1$ to $\mathrm{S} 1$, without inclusion of the femoral heads, or incorrect positioning, particularly of the upper limbs).

\section{Radiography}

The radiographic parameters were collected by two physicians, taking the average of the two parameters as the final value. Differences in scoliotic curvature, Risser Stage, LLD or PO severity (less than $1,1-1.5 \mathrm{~cm}$ or $>1.5 \mathrm{~cm}$ ) were again reviewed by the two evaluators. The posture implemented in the radiographic acquisition mirrors that advocated by the Scoliosis Research Society (SRS) i.e. plain full-length radiographs performed in the orthostatic position, with the anterior superior iliac spine parallel to the cassette and the beam aimed at T10. Lateral incidences were performed maintaining a horizontal gaze, with the beam at $90^{\circ}$ to that used for the PA radiography, with the anterior superior iliac spine perpendicular to the film and with the right side of the patient to the cassette. Both feet were parallel to the shoulders, 20 to $25 \mathrm{~cm}$ apart, and with the fingertips resting on the clavicles.

The whole procedure was supervised by two radiology technicians at the time of radiographic acquisition, to ensure minimal variability in the results.

\section{Parameters}

The parameters evaluated were: age, sex, Risser Stage (US Risser Staging System) ${ }^{22}$ (RS), triradiate cartilage (TC), scoliotic curvature differentiated according to the Lenke classification, leg length discrepancy, evaluated by a horizontal line running through the uppermost portion of the femoral head (LLD), and pelvic obliquity, measured by a horizontal line drawn between the most proximal point on the iliac crest and the difference between this line and the upper portion of the contralateral iliac crest.

\section{Statistical analysis}

Parametric data are presented as mean and standard deviation (SD). Nonparametric data are presented as median and interquartile range, and tested using the Mann-Whitney $U$ test, the Kruskal-Wallis test and Spearman's correlation coefficient. Significance was assumed as a $p$-value $<0.05$. Statistical analysis was performed using IBM SPSS Statistics ${ }^{\circledR}$ (Version 25; Armonk, NY: IBM Corp.) and Excel $2017^{\circledR}$ (2017; Redmond, WA: Microsoft Corp.).

\section{Ethics committee}

As this work is retrospective, based solely on the imaging study without direct contact with patients, interviews, or application of scores, the hospital where the study was performed does not require approval by the ethics committee.

\section{RESULTS}

The mean age of the patients was \pm SDof $12.44 \pm 2.38$ years; $76.3 \%$ were female and $23.8 \%$ were male. The main coronal curvatures were $21.83 \pm 15.68^{\circ}$ and these were divided into 3 groups: patients with a scoliotic Cobb angle of $10-20^{\circ}, 20-45^{\circ}$ and $>45^{\circ}$, with $72.5 \%, 15.0 \%$ and $12.5 \%$, respectively. According to the Lenke classification for scoliotic curves, 24 different curvatures were found. The most frequent were 1AN (25.0\%), 1BN (13.8\%), 5BN (11.3\%), 5AN (7.5\%), 5CN (7.5\%) and $6 \mathrm{CN}(5 \%)$, making a total of $70.1 \%$ of the sample.

Regarding the location of the main curvatures, $32.5 \%$ were thoracic, $53.8 \%$ thoracolumbar and $13.8 \%$ lumbar. The coronal balance showed a mean value \pm SD of $-0.49 \pm 0.15 \mathrm{~cm}$ and the sagittal balance of $-1.14 \pm 1.33 \mathrm{~cm}$, with sagittal decompensations ranging from -8.30 to $5.77 \mathrm{~cm}$. LLD evaluated between the femoral heads presented a mean value of $0.52 \pm 0.50 \mathrm{~cm} ; 84.4 \%$ had a discrepancy of less than $1 \mathrm{~cm}, 14.3 \%$ of $1-1.5 \mathrm{~cm}$, and only one patient had a discrepancy of more than $1.5 \mathrm{~cm}$. The pelvic obliquity presented similar values to those found in the evaluation of discrepancy from the femoral heads, with a mean value of $0.55 \pm 0.55 \mathrm{~cm}$. An analysis was also performed dividing the scoliotic sample into those with perfect alignment (LLD less than $0.10 \mathrm{~cm}$ ) and those without perfect alignment. We concluded that even when there is a small misalignment of the lower limbs, the right lower limb is much more likely to be the longest one, as $45.6 \%$ of the population had a longer right lower limb vs $26.6 \%$ with a longer left lower limb. The remainder were considered perfectly aligned.

When conducting a more in-depth analysis of LLD, we found a tendency for the coronal balance to shift to more negative values when there is a left shortened lower limb. Therefore, there is a propensity for a coronal imbalance toward the shorter lower limb between patients with a smaller left limb compared to those with a smaller right limb, practically with statistical significance $(p=0.052)$ (Table 1). The magnitude of the LLD did not have a statistically significant correlation with the scoliotic curvature/Cobb angle. However, these results could be different in a population with higher leg length discrepancy values.

Thus, for a population with a small LLD, the latter had a greater influence on the coronal balance than on the magnitude of the scoliotic curvature. 
On the other hand, when the LLD was evaluated for different locations of the main scoliotic curvature, namely between the scoliotic population with a major thoracolumbar and a major lumbar curvature, the mean LLD value was significantly different $(p<0.01)$. It was found that those with a major lumbar scoliotic curvature had a mean LLD that was about twice that of the other group $(0.88 \pm$ $0.39 \mathrm{~cm}$ vs $0.43 \pm 0.42 \mathrm{~cm}$ ). There were no statically significant differences between the Risser Stage extremes (0 and 5), despite the fact that patients with greater skeletal maturity presented higher mean LLD values than those with immature skeletons. Also the correlations between LLD, PO, CCA, SB, RS and LL were not statistically significant (Table 2). The Risser Stage most frequently found was 0 , corresponding to $43.8 \%$ of the cases (Table 3 ). The TC was found to be mostly closed (67.5\% of the study sample), and all patients with open TC presented a Risser Stage of 0 .

Although the female gender had a great importance in the studied sample and therefore in the AIS (76.3\%), there was no significant difference from male patients in relation to the Risser Stage values, TC, LLD (assessed through femoral head discrepancy and evaluation of pelvic obliquity) and severity of the scoliotic curvature.

Table 1. The influence of leg length discrepancy side on coronal balance.

\begin{tabular}{c|c|c}
\hline Leg length discrepancy side & $\begin{array}{c}\text { Coronal balance } \\
{[\text { median (IR)] }}\end{array}$ & p- value \\
\cline { 1 - 2 } Perfectly aligned $(<0.1 \mathrm{~cm})$ & $-0.73(2.37)$ & \multirow{2}{*}{$0.169^{*}$} \\
\hline Left lower limb larger & $0(2.08)$ & \\
\hline Right lower limb larger & $-0.69(1.59)$ & \\
\hline IR - interquartile range; * $p=0.052$ between left lower limb larger and right lower limb larger
\end{tabular}

Table 2. Relationship between LLD, PO, CCA, SB, RS and LL.

\begin{tabular}{c|c|c|c}
\hline Variables & $\mathbf{r}$ & $\mathbf{r}^{2}$ & $\mathbf{p}$-value \\
\hline Leg length discrepancy vs Pelvic obliquity & 0.788 & 0.621 & $<0.001$ \\
\hline Leg length discrepancy vs CCA & -0.107 & 0.011 & 0.346 \\
\hline Leg length discrepancy vs Sagittal balance & -0.159 & 0.025 & 0.327 \\
\hline Leg length discrepancy vs Risser stage & 0.046 & 0.002 & 0.69 \\
\hline Leg length discrepancy vs Lumbar lordosis & 0.116 & 0.013 & 0.334 \\
\hline Pelvic obliquity vs Sagittal balance & -0.202 & 0.041 & 0.087 \\
\hline Pelvic obliquity vs Risser stage & -0.098 & 0.01 & 0.386 \\
\hline Pelvic obliquity vs Lumbar lordosis & 0.076 & 0.006 & 0.528 \\
\hline
\end{tabular}

Table 3. Descriptive statistics of skeletal maturity.

\begin{tabular}{c|c|c}
\hline Risser Stage & $\mathbf{n}$ & $(\%)$ \\
\hline 0 & 35 & $(43.8)$ \\
\hline 1 & 7 & $(8.8)$ \\
\hline 2 & 3 & $(3.8)$ \\
\hline 3 & 8 & $(10)$ \\
\hline 4 & 13 & $(16.3)$ \\
\hline 5 & 14 & $(17.5)$ \\
\hline
\end{tabular}

\section{DISCUSSION}

Leg length discrepancy greater than $3 \mathrm{~cm}$ causes distinct gait and posture disorders. The bigger the difference, the greater and more distinct the disorders. The frequency of their occurrence is equal to the frequency of their causes. ${ }^{23}$ However, a slight leg length discrepancy of up to $2 \mathrm{~cm}$ is quite common. In screening examinations performed in the years 1992-2002 by the staff of the Centre of Rehabilitation for Children and Adolescents, LLD was found in about $10 \%$ of a population of primary school children. Stricker and Hunt reported a prevalence of LLD in adults of around 15\%. In about $95 \%$ of cases, the reasons for its occurrence are not known. ${ }^{24-26}$ Our sample corroborates the published results, with slight discrepancies $(<1 \mathrm{~cm})$ in the majority of the population. Jan W et al. reported a shortening of the left lower limb in $86 \%$ of cases of children and adolescents treated for LLD. In our population, $63.7 \%$ of the sample revealed a shorter left lower limb relative to the contralateral limb.

Small leg length discrepancy is not felt by the individual, and it does not result in noticeable disorders in gait parameters or, if it is noticed, the observed changes are insignificant. Thus, it is often neglected by the examining person. However, even such a small discrepancy causes pelvic obliquity in the frontal plane, which in turn causes scoliosis in the lumbar region. Based on this study we verified that in an AIS population with small LLD values, the magnitude of the shortening has a stronger impact on the location rather than on the dimension of the main scoliotic curvature. We found that lumbar main scoliotic curvatures were more closely associated with lower limb discrepancies than proximal scoliotic main curvatures.

These changes are the result of asymmetry of spine static and dynamic load, as well as intervertebral disc dislocation. ${ }^{26-28}$ Kowalik-Nitera found LLD in $71 \%$ of patients treated surgically due to lumbar disc herniation. ${ }^{29}$ This fact demonstrates the importance of the problem. In the current literature (the last ten years) there have been practically no studies focusing on small discrepancies. Further studies should be performed to verify the importance of slight LLD in the development and type of AIS and other spine disturbances, particularly in the lumbar region.

\section{CONCLUSIONS}

The initial analysis of this study effectively proves a female majority in the domain of adolescent idiopathic scoliosis. In most patients with leg length discrepancy, it is the left side that is shortened. Also, the magnitude of the LLD is closely related to the location of the main scoliotic curvature and the coronal balance. These results demonstrate that in a population with AIS and small LLD values, the extent of the shortening has a stronger impact on the location than on the dimension of the scoliotic curvature. A more thorough study on the importance of LLD $<1 \mathrm{~cm}$ in the development of biomechanical changes in the spine would therefore be of great interest.

All authors declare no potential conflict of interest related to this article.

CONTRIBUTION OF THE AUTHORS: Each author made significant individual contributions to this manuscript. EMP (0000-0002-4036-7478)*, JA $(0000-0002-7468-085 X)^{\star}$, AMC $(0000-0002-5363-8628)^{\star}$, MMS(0000-0002-6214-8460) ${ }^{\star}, \mathrm{JM}(0000-0002-0296-1097)^{\star}$, AT $(0000-0002-9617-8473)^{\star}$, and AM (0000-0001-7287-7475)* certify that each author participated in and contributed sufficiently to the work to take public responsibility for the suitability of the experimental design and method, and that this final version was reviewed and approved for submission and/or publication. We also certify that the sequence of authorship below is identical to that shown in the submitted manuscript. ${ }^{\star}$ ORCID (Open Researcher and Contributor ID).

\section{REFERENCES}

1. Enjolras O, Chapot R, Merland JJ. Vascular anomalies and the growth of limbs: a review. J Pediatr Orthop B. 2004:13(6):349-57.

2. Aaron $A D$, Eilert ED. Results of Wagener and llizarov methods of limb-lengthening. J Bone Joint Surg A. 1996;78(1):20-9.

3. Stricker SJ, Hunt T. Evaluation of leg discrepancy in children. Int Pediatr. 2004;19(3):134-42.

4. Walsh M. Leg length discrepancy - an experimental study of compensatory changes in three dimensions using gait analysis. Gait Posture. 2000;12(2):156-61.
5. Young RS, Andrew PD, Cummings GS. Effect of simulating leg length inequality on pelvic torsion and trunk mobility. Gait Posture. 2000:11:217-23.

6. Zabjek KF, Leroux MA, Coillard C, Martinez X, Griffet J. Simard G, et al. Acute postural adaptation induced by shoe lift in idiopathic scoliosis patients. Eur Spine J. 2001:10(2):107-13.

7. D'Amico M. Scoliosis and leg asymmetries: a reliable approach to assess wedge solutions efficacy. Stud Health Technol Inform. 2002;88:285-9 
8. Abaziewicz L., Nowakowski A. Scoliosis and faulty posture [Polish]. Chir Narz Ruchu Ortop Pol. 1996:61(3):247-50

9. Rose R. Fuentes A, Hamel BJ, Dizialo DJ. Pediatric leg length discrepancy: causes and treatments. Orthop Nurs. 1999;18(2):21-9.

10. Skwarcz A, Majcher P. Rehabilitation in scoliosis. In: Medical rehabilitation [Polish]. Wroc aw: Urban \& Partner; 2003. p. 185-237.

11. Raczkowski JW, Daniszewska B, Zolynski K. Functional scoliosis caused by leg length discrepancy. Arch Med Sci. 2010;6(3):393-8.

12. Luk KD, Lee CF, Cheung KM, Cheng JC, Ng BK, Lam TP, et al. Clinical effectiveness of school screening for adolescent idiopathic scoliosis: a large population-based retrospective cohort study. Spine (Phila Pa 1976). 2010;35(17):1607-14.

13. Soucacos PN, Zacharis K, Gelalis J, Soultanis K, Kalos N, Beris A, et al. Assessment of curve progression in idiopathic scoliosis. Eur Spine J. 1998;7(4):270-7.

14. Tan KJ, Moe MM, Vaithinathan R, Wong HK. Curve progression in idiopathic scoliosis: follow-up study to skeletal maturity. Spine (Phila Pa 1976). 2009;34(7):697-700.

15. Wu H, Ronsky JL, Cheriet F, Harder J, Kupper JC, Zernicke RF. Time series spinal radiographs as prognostic factors for scoliosis and progression of spinal deformities. Eur Spine J. 2011;20(1):112-7.

16. Hidekazu S, Kenji E, Jun M, Hiroto K, Hidetoshi T, Kengo Y. Clasped position for measurement of sagittal spinal alignment. Eur Spine J. 2010;19(5):782-6.

17. Aota Y, Saito T, Uesugi M, Ishida K, Shinoda K, Mizuma K. Does the fists-on-clavicles position represent a functional standing position? Spine (Phila Pa 1976). 2009;34(8):808-12.

18. Faro FD, Marks MC, Pawelek J, Newton PO. Evaluation of a functional position for lateral radiograph acquisition in adolescent idiopathic scoliosis. Spine (Phila Pa 1976). 2004;29(20):2284-9.
19. Horton WC, Brown CW, Bridwell KH, Glassman SD, Suk SI, Cha CW. Is there an optima patient stance for obtaining a lateral 36 radiograph? A critical comparison of three techniques. Spine (Phila Pa 1976). 2005;30(4):427-33.

20. Marks M, Stanford C, Newton P. Which lateral radiographic positioning technique provides the most reliable and functional representation of a patient's sagittal balance? Spine (Phila Pa 1976). 2009;34(9):949-54.

21. Stokes IA. Three-dimensional terminology of spinal deformity. A report presented to the scoliosis research society by the scoliosis research society working group on 3-D terminology of spinal deformity. Spine (Phila Pa 1976). 1994;19(2):236-48.

22. Bitan FD, Veliskakis KP, Campbell BC. Differences in the Risser grading systems in the United States and France. Clin Orthop Relat Res. 2005;(436):190-5.

23. Raczkowski JW, Daniszewska B, Zolynski K. Functional scoliosis caused by leg length discrepancy. Arch Med Sci. 2010;6(3):393-8.

24. Stricker SJ, Hunt T. Evaluation of leg discrepancy in children. Int Pediatr. 2004;19(3):134-42

25. Raczkowski JW. Faulty postures in children from elementary schools. In: Anthropology and Medicine [Polish]. Poland: University of Lodz; 1996. p. 291-300.

26. Gurney B. Leg length discrepancy. Gait Posture. 2002;15:195-206.

27. Bhave A, Paley D, Herzenberg JE. Improvement in gait parameters after lengthening for treatment of limb-length discrepancy. J Bone Joint Surg Am. 1999;61(4):529-34.

28. Song KM, Halliday SE. The effect of limb length discrepancy on gait. J Bone Joint Surg 1997:79(11):1690-8

29. Nitera-Kowalik A. Thermographical evaluation of effectiveness of rehabilitation exercises in patients after microsurgical treatment of lumbo-sacral spine. Medical University of Lodz; 2004. 